SJ Quinney College of Law, University of Utah Utah Law Digital Commons

Utah Law Faculty Scholarship

Utah Law Scholarship

2019

\title{
Adaptive Management for Ecosystem Services at the Wildland-Urban Interface
}

Robin Kundis Craig

S.J. Quinney College of Law, University of Utah, robin.craig@law.utah.edu

J.B. Ruhl

Vanderbilt University Law School

Follow this and additional works at: https://dc.law.utah.edu/scholarship

Part of the Environmental Law Commons, and the Natural Resources Law Commons

\section{Recommended Citation}

Craig, Robin Kundis and Ruhl, J.B., "Adaptive Management for Ecosystem Services at the Wildland-Urban Interface" (2019). Utah Law Faculty Scholarship. 152.

https://dc.law.utah.edu/scholarship/152

This Article is brought to you for free and open access by the Utah Law Scholarship at Utah Law Digital Commons. It has been accepted for inclusion in Utah Law Faculty Scholarship by an authorized administrator of Utah Law Digital Commons. For more information, please contact

valeri.craigle@law.utah.edu. 


\title{
ADAPTIVE MANAGEMENT FOR ECOSYSTEM SERVICES AT THE WILDLAND-URBAN INTERFACE
}

\author{
Robin Craig and J.B. Ruhl
}

\begin{abstract}
Managing the wildland-urban interface (WUI) is a widely-recognized land use problem plagued by a fractured geography of land parcels, management jurisdictions, and governance mandates and objectives. People who work in this field have suggested a variety of approaches to managing this interface, from informal governance to contracting to insurance. To date, however, none of these scholars have fully embraced the dynamism, uncertainty, and complexity of the WUI-that is, its status as a complex adaptive system. In focusing almost exclusively on the management of this interface to control wildfire, this scholarship largely ignores the factor that rampant wildfire is itself the product of incursions into important ecosystem services on both sides of the interface. In many cases, people tend to expand out towards the wildland not just for economics (cheaper housing) but also because of a suite of ecosystem services that are readily accessible at the interface, including aesthetics, a cleaner environment, and recreational opportunities. As the wildfire problem amply demonstrates, these settlers then become upset when other aspects of ecosystem function invade their lives, but those invasions include not just wildfire disasters but also more pernicious problems such as diseases, allergens, and wildlife. As such, development at the WUI can create a multifaceted desire to control several "undesirable" aspects of ecosystem function while simultaneously promoting the ecosystem services that residents desire, complicating land use management on both sides of a line that is itself often moving or transforming into a transition or buffer zone. To focus solely on wildfire, in other words, may oversimplify an increasingly complex management problem with significant policy implications.

While we cannot and will not attempt to resolve all of these policy issues in this article, we do propose that adaptive management may provide a mechanism for dealing with the complexity of managing changing ecosystem functions and services at the WUI, even when-and perhaps especially because-the private lands and wildlands are usually subject to different land use regimes. We begin with an overview of adaptive management, then discuss the hard but common case of fractured landscape management. We then explore the potential for adaptive management to help negotiate this fractured landscape in a changing world, starting with the classic issue of wildfire management but also suggesting possible expansions.
\end{abstract}




\section{INTRODUCTION}

Managing the wildland-urban interface (WUI) is a widely-recognized and growing land use problem. The federal government defines the WUI as areas "where humans and their development meet or intermix with wildland fuel" (USFS et al. 2001: 753). A 2018 study in the Proceedings of the National Academy of Sciences (PNAS) concluded that "the WUI was widespread in 2010, covering 9.5\% of the conterminous United States ..., and that the WUI grew rapidly from 1990 to 2010 in all its aspects" (Radeloff et al. 2018: 3315). Indeed, growth at the WUI showed the greatest increase in this period of any land use category, and "[n]ew WUI area totaled 189,000 [square kilometers], an area larger than Washington State" (Radeloff et al. 2018: 3316). Most of that development was residential housing: " $43 \%$ of all new houses were built there, and $61 \%$ of all new WUI homes were built in areas that were already in the WUI in 1990 (and remained in the WUI in 2010)" (Radeloff et al. 2018: 3316). Regionally, the East saw the largest absolute gains in WUI development, mostly in WUI areas where development had already begun by 1990, but the northern Rocky Mountains experienced the most rapid rates of new development incursions into the WUI (Radeloff et al. 2018). Notably, "housing growth was unambiguously the main cause for new WUI areas," and "new houses were the cause of $>80 \%$ of WUI growth in all states except Delaware, the District of Columbia, Maryland, and New Jersey" (Radeloff et al. 2018: 3316). In short, the WUI has become the go-to destination for this nation's new residential development, and with that has come a plethora of landscape-level management challenges. 
The 2010 Wildland-Urban Interface of the Conterminous United States

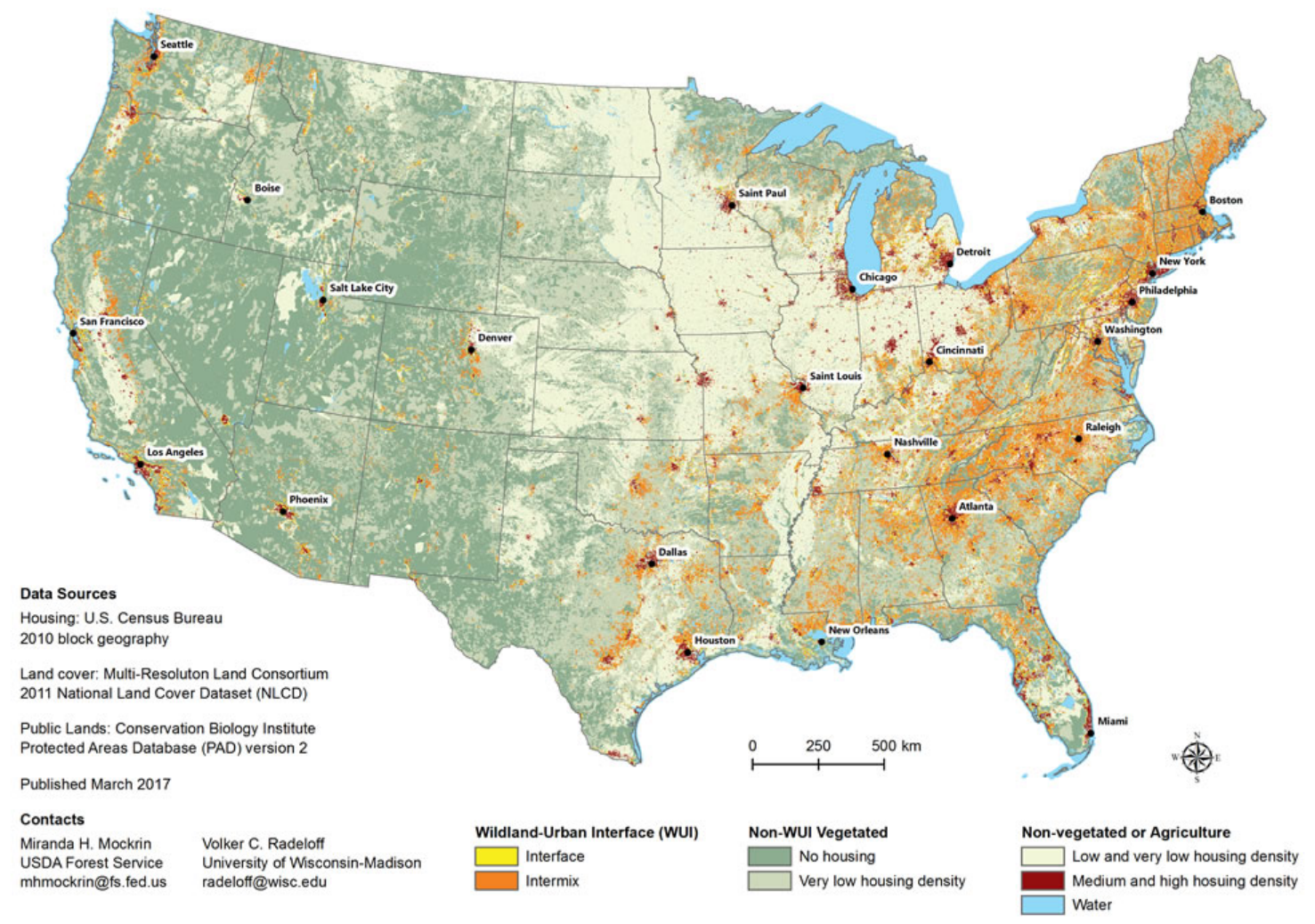

Figure 1. Map of US WUI in 2010.

Source: U.S. Forest Service, available at https://www.nrs.fs.fed.us/data/wui/.

Development in the WUI creates risks for both the humans moving in and the species and ecosystems already there. The risk common to both, which garners most of the management attention, is of course wildfire. Specifically, the WUI

is the area where wildfires pose the greatest risk to people due to the proximity of flammable vegetation. Wildfires frequently burn houses in the WUI, and are most difficult to fight there. Furthermore, the WUI is where people often ignite wildfires, and the vast majority of fires are human-caused. . . . [C]limate change will increase fire frequency in the future, including in the WUI (Radeloff et al. 2018: 3314).

Wildfire is both dramatic and expensive, and people exposed to wildfire risk demand swift and effective responses. Small wonder, then, that the scholarship examining WUI governance has focused almost exclusively on wildfire management (e.g., Trego 2012; Reilly 2015; Miller et al. 2016; Miller 2017; Burton 2018). Scholars who work in this field have suggested a variety of approaches to managing this interface. To compare just two recent examples, Stephen Miller, Jaap Vos, and Eric Lindquist have argued in favor of 
iterative community-engaged wildfire planning and incentive systems both to respond to current wildfire risks and to adjust as those risks change over time (Miller et al. 2019). Karen Bradshaw and Dean Lueck, in contrast, have focused on the role of contracting among different property owners to manage the landscape-level problem of wildfire at the WUI (Bradshaw and Lueck 2015).

Unlike either of these approaches, we seek not to so much to offer a "solution"although we do propose that cross-jurisdictional adaptive management will help-but to open the lens through with the problem is framed. Specifically, we argue, none of the WUI scholars to date have fully embraced the dynamism, uncertainty, and complexity of the WUI as a holistic system beyond wildfire. Much of the legal scholarship in this area seeks to find ways to improve human control over problems at the WUI. For example, Bradshaw and Lueck offer contracts as a "mechanism for consolidating control of natural resources" (Bradshaw and Lueck 2015: 2547). We're not so sure that "control" is the right goal for management at the WUI to begin with, especially during the Anthropocene and in light of the increasing impacts from climate change. Even if it is, however-or, more likely, if political realities make attempts at "control" unavoidable-managers cannot achieve that aim by managing and planning for only the problematic symptoms, like wildfire, of disturbances within the more complex social-ecological dynamics at play.

"Control of wildfire" thus distorts the WUI management focus in several ways. Most basically, it shifts focus away from other management issues. Development at the WUI brings with it several threats beyond wildfire to the ecosystems on the wildland side of the interface, while those ecosystems offer several challenges other than wildfire to homeowners and their communities. In short, as Radeloff et al. (2018) recognized, management at the WUI must deal with many more issues than just wildfire, issues that involve both human safety and ecosystem integrity:

The close proximity of houses and wildland vegetation does more than increase fire risk. As houses are built in the WUI, native vegetation is lost and fragmented; landscaping introduces nonnative species and soils are disturbed, causing nonnatives to spread; pets kill large quantities of wildlife; and zoonotic disease, such as Lyme disease, are transmitted (Radeloff et al. 2018: 3314).

These issues are becoming ever more complex as climate change is altering the baselinefor both the new human residents and the existing ecosystems - of what qualifies as "normal."

In addition, "control of wildfire" focuses management energy on one symptom of disturbance rather than on the underlying dynamics of the WUI. To better manage the array of problems facing the WUI, we propose that the WUI should be conceptualized as a complex adaptive social-ecological system (because it is) and that adaptive management for ecosystem services provides a tool that better allows managers on both "sides" of the WUI to deal with systemic risk and the changing landscape in the face of potentially clashing management desires that are both broader than, and potentially contributory to, wildfire. Complex adaptive systems are systems "in which large networks of components with no central control and simple rules of operation give rise to complex collective 
behavior, sophisticated information processing, and adaptation via learning or evolution" (Mitchell 2009: 13). Adaptive management in decision making relies on iterative cycles of goal determination, model building, performance-standard setting, outcome monitoring, and standard recalibration (Craig and Ruhl 2014). Ecosystem services are "[t]he direct and indirect contributions of ecosystems to human wellbeing" (TEEB n.d.). In many cases, human residents, urban planners, and wildland managers working in the complexity of the WUI will value different suites of ecosystem services, even when they agree that uncontrolled wildfire should be suppressed (and keeping in mind that they may also disagree on the value of wildfire more generally). Within this complex adaptive system model, we argue, wildfire is the cascade failure effect of systemic risk that has built up in the system for a wide variety of reasons stemming from those contested ecosystem service preferences. Under any account of adaptive management theory, this is a context ripe for its application.

Thus, focusing solely on wildfire as the management target oversimplifies an increasingly complex management problem with significant policy implications, including local land use planning and zoning, housing affordability, homeowner assumption of risk, potential liability on all sides, disaster and public health preparedness, utility and other infrastructure management, insurance industry policy, and the achievable management goals for remaining wildland areas (e.g., can they remain "wilderness"). Moreover, that limited focus may, perversely, actually fail to address some of the underlying causes of the increase in wildfire risk - that is, development at the WUI itself often significantly impairs the ecosystem processes that previously prevented large and uncontrolled wildfires from occurring. While we cannot and will not attempt to resolve all of these issues in this Article, we do propose that adaptive management may provide a mechanism for dealing with the complexity of managing changing ecosystem functions and services at the WUI, even when - and perhaps especially because - the private lands and developed public lands of urban areas and their nearby wildlands are usually subject to different land use regimes.

We begin in Part I by outlining a model of the WUI as a complex adaptive socialecological system and of wildfire as a cascade failure. Part II provides an overview of ecosystem services and of adaptive management. Part III then contextualizes adaptive management of ecosystem services in the context of different land use regimes that in the WUI are often interspersed in a "blotchy" mosaic rather than abuting in neat "long and skinny" lines. In Part IV we then explore the potential for adaptive management to help negotiate this fractured landscape in a changing world, beginning with the identification of desirable and undesirable ecosystem services.

\section{CONCEPTUALIZING THE WUI AS A COMPLEX ADAPTIVE SOCIAL- ECOLOGICAL SYSTEM}

The term "wildland-urban interface" suggests a place where urban backyards abut a wilderness - a sharp and continuous line demarking the end of nature and the beginning of the built environment. While such places do exist, the WUI is in fact a crazy-quilt mosaic of land uses and political jurisdictions. As Figure 2, a map of the Spanish province of Catalonia (Alcasena et al. 2018) shows, the WUI consists of interface communities where 
structures directly abut wildland fuels and there is a clear line of demarcation between residential, business, and public structures and wildland fuels, and intermix communities where structures are scattered throughout a wildland area, there is no clear line of demarcation, and wildland fuels are continuous outside of and within the developed area. (USFS et al. 2001). In the Catalonia study by Alcasena et al. (2018), intermix WUI zones accounted for three percent of the land area but 16 percent of the building structures, while interface WUI zones accounted for seven percent of the land mass but 64 percent of the structures. In other words, while the WUI accounted for only 10 percent of the land area, 80 percent of all structures in Catalonia were located in WUI zones, most of both of which were concentrated in two counties.

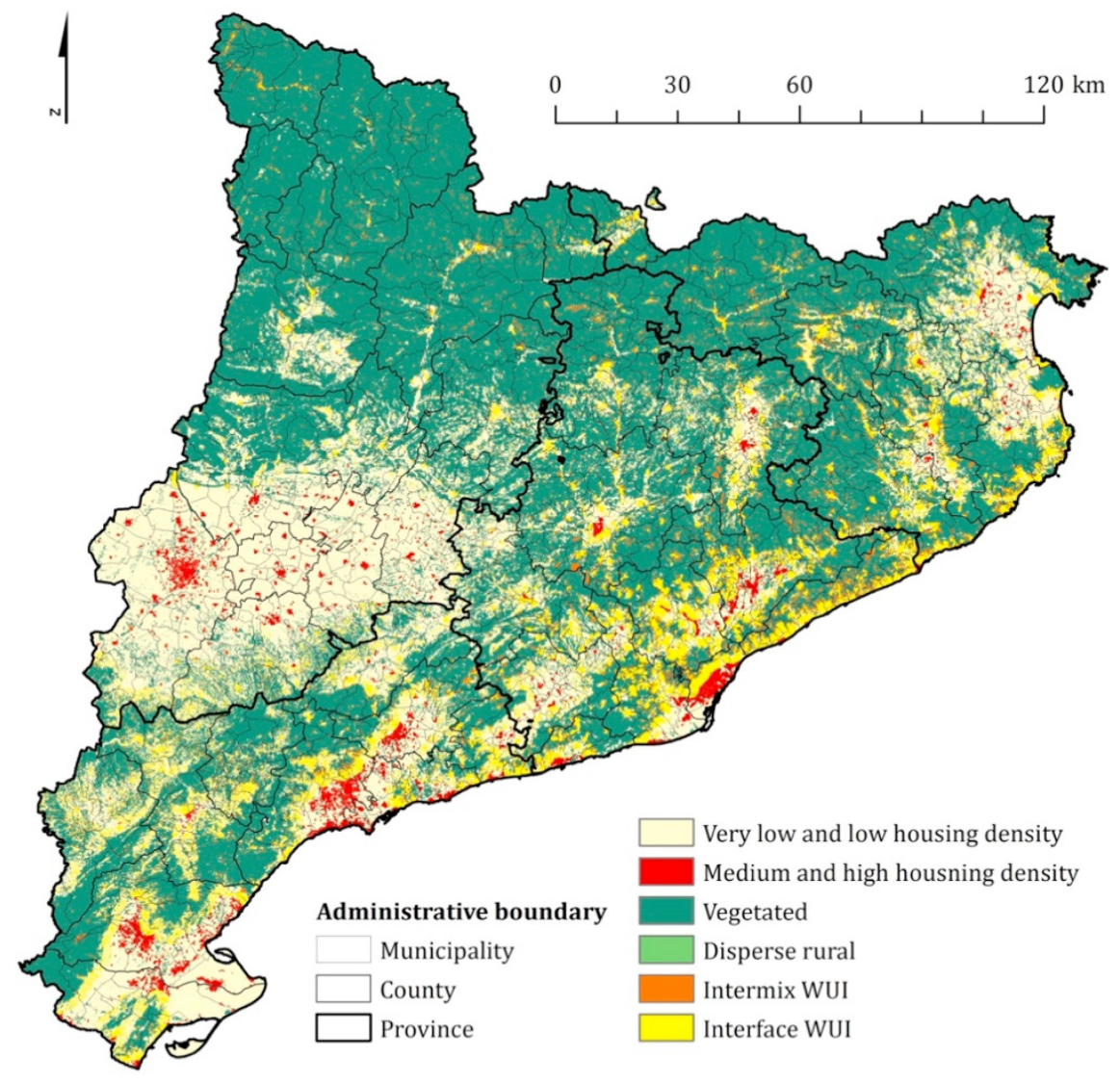

Figure 2. WUI map of the Province of Catalonia, Spain.

Source: Alcasena et al. (2018), reproduced with permission of the authors.

In short, the WUI not a social system next to an ecological system, it is an intertwined social-ecological system (SES).

SESs are composed of multiple subsystems and internal variables within these subsystems at multiple levels analogous to organisms composed of organs, organs of tissues, tissues of cells, cells of proteins, etc. In a complex 
SES, subsystems such as a resource system (e.g., a coastal fishery), resource units (lobsters), users (fishers), and governance systems (organizations and rules that govern fishing on that coast) are relatively separable but interact to produce outcomes at the SES level, which in turn feed back to affect these subsystems and their components, as well other larger or smaller SESs (Ostrom 2009: 419).

The study of SESs has become a mainstream scientific discipline, as "all humanly used resources are embedded in complex, social-ecological systems" (Ostrom 2009: 419)

Given the dynamic, multi-scalar properties of SESs, researchers in land use and other disciplines studying SESs are increasingly turning to complexity science to conceptualize and model this kind of dynamic, complex land use setting (Samet et al. 2013). The focus of complexity science is complex adaptive systems, systems "in which large networks of components with no central control and simple rules of operation give rise to complex collective behavior, sophisticated information processing, and adaptation via learning or evolution" (Mitchell 2009: 13). The key premise is that there is a difference between complexity in the sense of "complicatedness" and complexity in the sense of how a system is constructed and behaves. The distinction goes to the essence of complexity science theory:

In a complicated world, the various elements that make up the system maintain a degree of independence from one another. Thus, removing one such element (which reduces the level of complication) does not fundamentally alter the system's behavior apart from that which directly resulted from the piece that was removed. Complexity arises when the dependencies among the elements become important. In such a system, removing one such element destroys system behavior to an extent that goes well beyond what is embodied by the particular element that is removed (Miller and Page 2007: 9).

One dominant attribute of complex adaptive systems is feedback between the system components - the connections through which information flows between them to trigger responses (Miller and Page 2007; Mitchell 2009). Another important property, driven largely by inter-component feedback, is emergence, the core idea of which is that the system exhibits macroscopic behavior that could not be predicted by examining the system components, interconnections, and interactions at microscopic scales (Miller and Page 2007; Mitchell 2009). A third central property of complex adaptive systems is selforganized structure, such that as system scale grows the system organizes spontaneously (with no central controller or plan) around a set of deep structural rules that lend stability to the system behavior (Miller and Page 2007: Mitchell 2009; Kauffman 1995). These three key system attributes then produce the adaptive capacity and resilience of a complex adaptive system and promote its evolution over time.

Alas, the feedback mechanisms and emergent properties characteristic of complex adaptive systems are the source of both system resilience and systemic risk. The term "systemic risk" has become closely associated with the financial system collapse of 2008 
(Anatwabi and Schwarz 2011; Grusen 1987), but the concept of systemic risk exposing a system to cascade failure is not limited to financial systems-it applies to all complex adaptive systems. Dirk Helbing (2013) of the Swiss Federal Institute of Technology defines systemic risk and cascade failure as

the risk of having not just statistically independent failures, but interdependent, so-called "cascading" failures in a network of $\mathrm{N}$ interconnected system components. That is, systemic risks result from connections between risks ("networked risks"). In such cases, a localized initial failure ("perturbation") could have disastrous effects and cause, in principle, unbounded damage as $\mathrm{N}$ goes to infinity....Even higher risks are multiplied by networks of networks, that is, by the coupling of different kinds of systems. In fact, new vulnerabilities result from the increasing interdependencies between our energy, food and water systems, global supply chains, communication and financial systems, ecosystems and climate (51).

We propose that the WUI is best understood as a complex adaptive socialecological system that, because of its rapid growth of interface and intermix communities over the past few decades, has in many areas built up immense systemic risk, with wildfire being one type of cascade failure. The WUI unquestionably is a SES (Paveglio et al. 2009; Paveglio et al. 2015), and it closely matches the definition of a complex adaptive systemit consists of large networks of components with no central control, where simple rules of operation give rise to complex collective behavior, sophisticated information processing, and social and ecological adaptation via learning or evolution. This model demands that wildfire management not be compartmentalized as a discrete management problem, or that wildfire be the management problem driving the management of the SES as a whole. Rather, managing the WUI requires stepping back and examining why it exists in the first place, what is driving its growth, and the sources of its systemic risk.

\section{FOUNDATIONS OF ECOSYSTEM SERVICES AND ADAPTIVE MANAGEMENT}

Why do so many people want to live near, next to, or within wildland areas, even though it exposes them to wildfire? For many, it is because wildland areas offer many amenities - they are peaceful and pretty, offer tremendous recreational opportunities, connect humans with nature, and generate significant economic activity around all of those attractions. They also are full of ticks and other vector insects, poison ivy and other toxic plants, potentially dangerous mammals, and fuel for wildfire. And there is no way to have the good without the bad. These positive and negative features of wildland areas flowing within their spaces and spilling into human communities can be characterized as types of ecosystem services, and the challenge of optimizing the flows of positive ecosystem services can be characterized as an exercise in adaptive management. 


\section{A. What Are Ecosystem Services?}

Ecosystem services are the economic benefits and other well-being that humans derive from ecosystems (Costanza et al. 2018). Under the widely-adopted typology developed in the Millennium Ecosystem Assessment (Millennium Ecosystem Assessment 2005), ecosystem services flow to human communities in four streams: (1) provisioning services are commodities such as food, wood, fiber, and water; (2) regulating services moderate or control environmental conditions, such as flood control by wetlands, water purification by aquifers, and carbon sequestration by forests; (3) cultural services include recreation, education, spiritual experiences, and aesthetics; and (4) supporting services, such as nutrient cycling, soil formation, and primary production, make the previous three service streams possible. For example, aquatic resources such as coastal wetlands can provide bountiful supplies of ecosystem services to human populations in all of these categories, including water, groundwater recharge, storm and flood mitigation, sediment control, water purification, climate regulation, water supply, and recreation.

The ecosystem services framework progressed from an academic research theme in the mid-1990s to a dominant public policy theme only a decade later (Ruhl and Salzman, 2007; Salzman 2006), with a small but growing number of applications now appearing in statutory and regulatory provisions (Ruhl 2015; Scarlett and Boyd 2011; Scarlett and Collins 2014). Indeed, in 2015 the White House's Council on Environmental Quality, Office of Management and Budget, and Office of Science and Technology issued a memorandum to all agencies in the Executive branch directing them to integrate identification and valuation of ecosystem services into their decision making (Council on Environmental Quality et al. 2015). Many of the public decision makers working at the WUI, such as the U.S. Forest Service, are deeply committed to the ecosystem services framework as a decision making driver (USFS 2012).

By explicitly describing ecosystems as providing economically valuable benefits to humans and proposing a scientifically-based argument for integrating those values into private and public decisions, the ecosystem services framework added human well-being to the case for conservation, which had before then depended largely on appeals to environmental well-being and intrinsic values of nature (National Research Council 2004). This new perspective and its potential to alter the dynamics of public and private resource management decision making, while not free of controversy, has invigorated scientific research, economic thought, and policy development (Costanza et al. 2018).

To the extent that it becomes an increasingly important goal of public and private land management, managing resources to enhance and maintain sustainable regulating and supporting services faces many challenges. Foremost is the difficulty of valuation. Using the ecosystem services framework in natural resources management contexts such as the WUI requires explicit identification of the natural capital supplying the services, the flows of services from those resources, the human populations benefitted from those services, and the value of those benefits (Ruhl et al. 2007). Active markets exist for provisioning services, and the value of cultural services, even when not fully captured in markets, can be estimated through techniques such as hedonic pricing and willingness to pay (Lant et al. 2008). By contrast, regulating and supporting services, which often have the qualities of 
non-market public goods, are far more difficult to quantify and value.

Also, many resources provide a suite of services, with different communities benefitting from different services at different spatial and temporal scales. For example, a national forest might support a regional timber industry, control sediment flux in a river that benefits a downstream local community, provide enhanced groundwater recharge that benefits a different local community, and sequester carbon to the benefit of the global population. It also can produce negative ecosystem service values, such as from wildfire. Tradeoffs could exist between different services, meaning prioritizing for one could favor its beneficiaries over the beneficiaries of the services that may experience decreased flows. This is precisely the problem we argue is at play in the WUI. Because regulating and supporting services are not so easily valued through markets and other observed behavior, they tend to lose out in the tradeoffs decisions inherent in both private markets and public policy (Ruhl et al. 2007). Much of the research and policy attention being devoted to the ecosystem services framework thus has been focused on how to develop economic valuation methods for regulating and supporting services so decision makers have better information at hand to evaluate tradeoffs between all types of ecosystem services (Salzman 2006).

\section{B. What Is Adaptive Management?}

Setting goals for the flow of ecosystem services from public or private lands is a decision land managers make in response to legal and policy contexts, market forces, and other factors. Once those goals are established, the complex and dynamic nature of socialecological systems presents a challenge to achieving them, both short-term and long-term. Managing for ecosystem services, in other words, is a challenging management undertaking. Because of its focus on decision making in complex, dynamic environments, the discipline of adaptive management has emerged over the past two decades as a widelyadopted method for implementing social-ecological management goals generally (Craig and Ruhl 2014). Adaptive management has proven easier in theory than in practice, but nevertheless it seems particularly well-suited for consideration as a decision-making model for the WUI.

Adaptive management involves iterative decision making following a structured, multistep protocol. The formal, structured decision process involves a "setup" phase, during which the decision-making actor specifies stakeholder involvement, management objectives, management actions, models, and monitoring plans, followed by an "iterative" phase, during which the actor specifies the decision-making process, follow-up monitoring, assessment, and feedback (Williams and Brown 2012). With roots in natural resources management theory, the adaptive management protocol has gained traction in public lands management in particular (Doremus et al., 2011; McFadden et al. 2011; Susskind et al. 2012.). It has also been applied or proposed in other policy contexts, including pollution control, financial regulation, environmental impact assessment, public health and safety, civil rights, and social welfare (Craig and Ruhl 2014).

Adaptive management is not always useful or appropriate. If a resource management context is relatively static, adaptive management is irrelevant-there is 
nothing about the problem requiring adaptation. However, many resource management contexts change dynamically over time in response to environmental conditions as well as management interventions (Williams 2011). The fundamental question in such contexts is whether we know enough about the dynamic processes (degree of uncertainty) to manipulate them (degree of controllability) without causing irreversible harm (degree of risk) (Allen and Gunderson 2011). The primary objective of adaptive management is to reduce uncertainty through integrative learning fostered in a structured, iterative decisionmaking process. This approach is most relevant for dynamic resource management contexts, such as the WUI, in which uncertainty and controllability are high and risk is low (at least in terms of complete irreversibility). By contrast, if uncertainty is low, investment in learning is unnecessary; if controllability is low, investment in learning is pointless; and if risk or irreversible transformation is high, investment in intervention could lead to severe and irreversible consequences (Allen and Gunderson 2011; Craig and Ruhl 2014).

Adaptive management is a resource-intensive decision-making method that relies on continuous monitoring, experimentation, assessment, and adjustment (Doremus 2011; Naeem et al. 2015), which will be no less the case when managing for ecosystem services at the WUI. Adaptive management thus requires consistent funding support over extended time frames and a tolerance for failure. These realities mean that institutional leaders manging WUI conditions must conclude that reducing uncertainty is sufficiently feasible and valuable to justify the costs and that their support for adaptive management persists beyond the initial authorization to practice it (Biber 2013). Most adaptive management theorists also include external stakeholder engagement as a critical condition for viability of adaptive management (Allen and Gunderson 2011). Stakeholder engagement allows the decision maker to learn from the affected community when shaping goals and protocols and to communicate decision making assumptions and rationales. Lastly, and flowing from those two factors, adaptive management only works if the accountability mechanisms for the decision makers, such as citizen suits and judicial review in the public agency context, do not suffocate the iterative decision process. This has been a challenge to implementing adaptive management for many resource management agencies (Craig and Ruhl 2014).

Even when there is reason to believe all of the foregoing factors could be put in place, some resource management contexts trigger highly normative boundaries that would not allow the degree of experimentation and decision adjustment needed for adaptive management to work. For example, the decision to designate an area as wilderness injects normative constraints regarding the value of natural conditions, thus limiting the range of possible adaptive management experiments. For adaptive management of ecosystem services at the WUI to have any traction at all, therefore, special attention must be given to the diverse mix of land use regimes and normative goals operating in the WUI.

\section{LAND USE REGIMES IN COLLISION AT THE WUI}

As the W and the U in the WUI acronym suggest, and Figures 1 and 2 make clear, the WUI is inherently a patchwork of different land use regimes, each of which has its own ecosystem services and adaptive management profile. It is therefore useful to consider how 
each land use regime operates independently, as well as what challenges arise when they collide and mix at the WUI.

\section{A. Land Use Regimes as Adaptive Management Platforms}

Broadly speaking, there are five major land use regimes relevant to the ecosystem services adaptive management context, any of which can be found operating under public or private ownership and at varying geographic and jurisdictional scales: (1) preservation; (2) dominant use; (3) multiple use; (4) developed; and (5) engineered (Ruhl 2016). These define more of a spectrum than sharply discrete regimes, but in many cases a short step across a political boundary can thrust one into a vastly different set of land use rules and ecosystem services goals, thereby changing how managers can apply adaptive management.

Scale and heterogeneity play important roles in defining the integrity of any land use regime. A small state park might be located in the heart of an urban city, and the city might abut a large national forest, in both cases imposing WUI management issues. Conditions in and decisions about each "regime" necessarily are influenced by the others, but ultimately the state parks department manages state parks, city planners manage large urban areas, and federal agencies manage national forests. Hence, while recognizing that coordination among diverse managers is necessary, it is useful to consider the extent to which the particular land use regimes they manage influence how ecosystem services goals are set and the role adaptive management can play in achieving them (Ruhl 2016). This perspective is of particular consequence at the WUI, where several or all of the regimes often bump into and mix with each other, and their positive and negative ecosystem services spill over regime boundaries.

\section{Preservation Regimes}

Preservation regimes seek to restore and secure sustainable ecosystems using a historical natural state as a reference point (Palmer and Ruhl 2015). Examples include public wilderness areas and private land preservation trusts. Preserved lands present a complicated picture for adaptive management of ecosystem services. On the one hand, as a general matter preserved lands are already providing cultural, regulating, and supporting services, given the management priority of sustaining the reference conditions of the ecosystem. However, these services are generally incidental to holding the historic reference point in place - they are the consequence, not the mandate - and usually lands under a preservation mandate, whether public or private, cannot be managed for production of provisioning services. These restrictions necessarily confine how managers can deploy adaptive management. For example, while managers of a public wilderness area or private land trust devoted to preserving natural conditions might use adaptive management to eradicate an invasive tree species to maintain historic reference conditions, it would be unacceptable to use adaptive management to introduce a non-native tree species to enhance carbon sequestration services, or to decide to harvest the timber for provisioning services.

In general, therefore, the flow of ecosystem services from preservation regimes is dictated 
by and incidental to the goal of maintaining the mandated reference conditions of the preserved ecosystem.

\section{Dominant Use Regimes}

Dominant use regimes prioritize one land use over others, but allow for additional uses so long as they are compatible with the assigned dominant use (Ruhl 2010). Often the priority use is a provisioning service. Examples include game management on public wildlife refuges, working ranchlands operating under conservation easements held by a land trust, and crop production on private agricultural lands. As in the case of preservation regimes, dominant use regimes are defined by a primary purpose and thus present some inflexibility to setting ecosystem services goals and using adaptive management to achieve them. The specified dominant use is usually not as narrowly constrained as is the historic reference conditions goal of preservation regimes, however, and the opportunity to allow for compatible uses introduces additional flexibility. These features allow for some degree of explicitly managing the resource to enhance regulating and supporting services while still achieving the dominant provisioning services goal. A wildlife refuge manager, for example, might alter game habitat management practices specifically to increase groundwater recharge services while still maintaining favorable conditions for wildlife sufficient to meet a dominant hunting use mandate. To the extent managing for a defined ecosystem services flow is compatible with the specified dominant use, using adaptive management to guide the ecosystem services management practices would be appropriate, assuming that the conditions for adaptive management are in other respects satisfied.

\section{Multiple Use Regimes}

Multiple use regimes balance and distribute several assigned land uses, some of which may be incompatible if co-loctaed, within the resource management area (Ruhl 2010). Examples include national forests and parks and private suburban and exurban communities with mixed commercial, residential, and open space uses. The multiple use balancing act can be both a blessing and a curse. On the one hand, the ability to arbitrate between competing uses provides management flexibility not available in preservation and dominant use regimes. On the other hand, this very flexibility creates tension between stakeholders representing the different competing land uses, such as recreation versus preservation versus timber harvesting, all of which cannot practicably happen in the same place. The decision-making environment is more amenable to setting ecosystem services goals and applying adaptive management, but the external pressures from interest groups may constrain adaptive decision making. Nevertheless, managing for regulating and supporting ecosystem services is likely to be consistent with one or more of the prescribed multiple uses, and adaptive management is inherently well-suited to balancing service trade-offs over time in response to changing environmental, social, and economic conditions. Multiple use regimes thus present a welcoming environment for using adaptive management to set and achieve goals for ecosystem services. 


\section{Developed Regimes}

Developed regimes, usually urban areas, have depleted most natural resources, although small pockets of natural areas and green space may be present (Green et al. 2015). Examples include the mix of public and private land uses in dense urban areas, some of which include small pocket parks, trees along streets, landscaping, and possibly some (likely stressed) natural areas. Managing for ecosystem services in such settings can be challenging given the limited natural capital base, inflexible land use patterns, and competing stakeholders. A small urban park, for example, has fixed boundaries and is subject to multiple stressors from external and internal sources, over which the park manager has little control. Trees along a street median present even fewer options for managing ecosystem service flows. Adaptive management may be useful for other purposes within urban jurisdictions, such as housing policy or public health response, but developed land use regimes present limited opportunities for managing the profile of ecosystem services, particularly regulating and supporting services. Strict land use controls in urban jurisdictions dictate and limit possibilities, making most parcels the equivalent of dominant use regimes and leaving only a limited stock of multiple use parcels, such as a city park, where decision makers can experiment with ecosystem service tradeoffs. Even for city parks, however, as with multiple use regimes, strong external stakeholder entrenchment in the existing balance of uses can constrain options. This is not to suggest that urban ecosystem services are unimportant or that city managers should not take opportunities to enhance the array of urban green spaces (Elmqvist et al., 2015; Luederitz et al. 2015), just that adaptive management of ecosystem services may be of limited application, relegated for example to incorporating more "green infrastructure" such as trees, grassy swales and rooftop gardens into new urban development and redevelopment projects. More adaptive management options may emerge, however, when city planners seek to incorporate more green infrastructure for specific purposes, such as storm water control under the Clean Water Act (see 33 U.S.C. § 1342(p), (s) (as amended 2019)).

\section{Engineered Regimes}

Engineered regimes involve substantial intervention in an existing land use to create or manipulate the environment specifically to produce a defined flow of ecosystem services, increasingly to enhance and maintain regulating and supporting services (Palmer and Ruhl 2015). The intervention may rely substantially on conventional engineering, such as construction of a beach dune system, or on more ecosystem-based solutions, such as a coastal wetlands restoration project (Temmerman and Kirwan 2015). Examples falling between those two extremes include private habitat banks and urban green infrastructure projects. Although these are generally small in scale, the imminent need to adapt to climate change may make engineered regimes such as constructed coastal wetlands of vital importance.

Although engineered regimes may on the surface look like the other regimes-for example, an engineered coastal wetland designed for storm surge protection might for all appearances look like a preservation or dominant use regime - engineered regimes present 
the resource manager with the greatest opportunity to engage in adaptive management from project conception and design to implementation and operation. The ecosystem services that the engineered regime is commissioned to produce in effect become the defining priority purposes of a dominant use regime, and the explicit understanding that the means of delivering the services are to be engineered establishes a decision-making environment that opens the door to using adaptive management more freely.

\section{B. The Blotchy WUI Land Use Regime Mosaic}

Wildland areas are managed under a variety of preservation, dominant use, and multiple use regimes. These can be adjacent as well as mixed, such a wilderness area (preservation) designated within a national forest (mixed use) near a wildlife refuge (dominant use). The built environment generally consists of mixtures of developed and engineered regimes. In the WUI, these many worlds bump into each other (interface) and blend together (intermix). Moreover, a diversity of private and public entities retain jurisdiction over their respective "pieces" of the WUI. Cities, counties, states, regional entities, and federal agencies own and administer public lands and regulate both public and private lands. Private entities from homeowners to shopping mall developers to timber companies own or lease lands in interface and intermix communities.

Viewed this way, the WUI acronym is unfortunate, because it conjures up an image of a tidy "long and skinny" dividing line between the wildland and urban worlds, when in fact a considerable portion of the WUI is interface. Richard Epstein (this volume) uses the "long and skinny" metaphor to describe property regime mismatches that occur when two regimes abut along a demarcation line that is long and line-like. A classic example is a linear pipeline. One landowner owns one regime - the long and skinny pipeline - while multiple other landowners own properties through which the pipeline corsses. Electric transmission lines and roadways are other examples. This linear intersection with multiple properties complicates siting of long and skinny projects, as any one intersected owner could resist the siting, thus leading to solutions such as eminent domain power to overcome holdouts. Uniform contracting models could also help manage how the intersecting owners relate (Bradshaw and Leuck 2015).

Physical systems also exhibit linear intersection problems, but rarely in as precise a demarcation as for pipelines and other linear infrastructure projects. Rather they tend to be more "fuzzy." Coastlines and rivers, for example, are dynamic - they move aroundand have associated areas such as esturaries and floodplians that blur sharp demarcations. Levess and seawalls are ways of sharpening the demarcation. While there may be one manager for the natural resource side of this kind of interface, the zone of influence of the resource on nearby built environments can be difficult to pin down, thus complicating the more one-to-one model that exists in infrastructure contexts.

Then there are regimes such as the WUI, which from quite a distance can look like long and skinny problems, but at more granular scales are quite "blotchy." As Alcasena et 
al. (2018) demonstrate in their study of Catalonia (Figure 3), the land cover regime in the WUI is a mosaic of different types jumbled together in fairly tightknit fasion. Unlike a classic long and skinny property problem, no one landowner necessarily controls all of one "side" of the WUI. To be sure, in some WUI contexts there is a true sharp long and skinny interface- e.g., along the border of a national park - and one landowner manages the wildland side. That management simplicity dissolves quickly in the intermix zone, however, and matters devolve even more so when the WUI runs through multiple public jurisdictions with various land use management regime mandates. Eminent doman would be an unwieldy tool for smoothing out the blotchy property regimes, both because of political resistancefrom private landowners and because multiple governments could be involved, while contracting between landowners would likely have very high transaction costs.

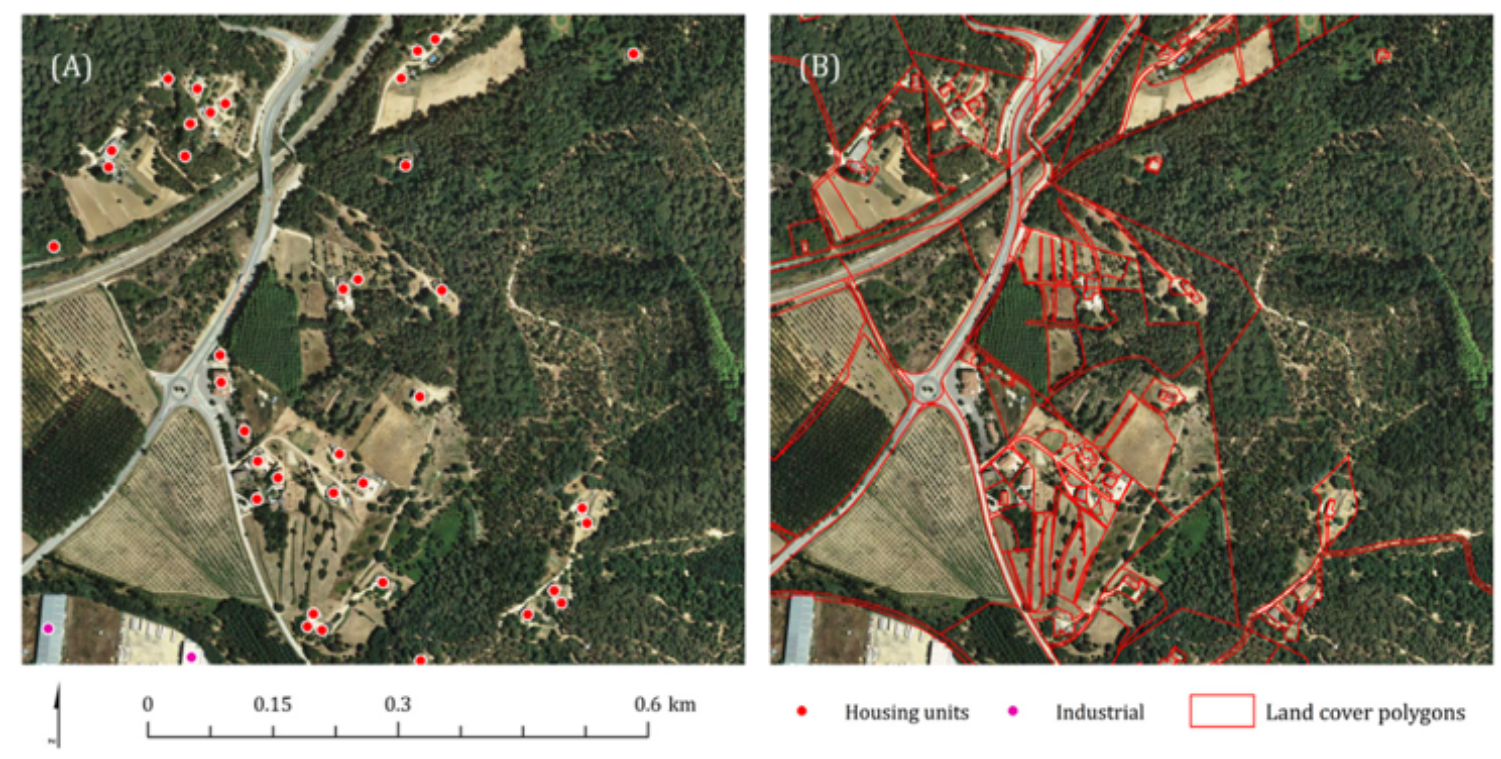

Figure 3. Close-up view of WUI in Catalonia showing land use polygons. Source: Alcasena et al. (2018), reproduced with permission of the authors.

The WUI is in this sense a landscape-level emergent property of this convergence and confluence of a multitude of ownership and management regimes - what complexity science calls a "system of systems" (Ruhl and Katz 2014). Using wildfire as the management challenge - as a kind of proxy for the WUI system of system-misses the point and, worse, could lead to more systemic risk. For example, there is evidence that federal investment in firefighting in the WUI has only intensified encroachment, as it subsidizes the built environment (Baylis and Boomhower 2019). To be sure, wildfire must be managed, but the drivers in the system that lead to wildfire go beyond forest fuel levels and homeowner landscape management. Better forest management and incentives or penalties to move homeowners towards better landscaping and building materials will no doubt be part of any solution, but landscape-level strategies that frame the WUI as a "virtual 
parcel" (Bradshaw and Leonard this volume), one of immense internal complexity, are needed. We offer one such approach.

\section{ADAPTIVE MANAGEMENT FOR ECOSYSTEM SERVICES AT THE WUI}

Ecosystem services offer a different way of framing the WUI management issue that is more likely to acknowledge and embrace the full complexity of that management problem. Specifically, we posit that governance at the WUI must seek to manage a clash in valuation of ecosystem services within a complex adaptive social-ecological system. Moreover, given this reality, a process like adaptive management for ecosystem services that can encompass simultaneously the variety of those services, the complexity of the system, the multitude of stakeholders, and a changing future is one worth embracing.

People move to the WUI for a variety of reasons. "Some move to live closer to nature, others to avoid government regulations or find a lower cost of living. There are also indigenous communities and people who work the land" (Pierre-Louis and White 2018). People who move to the WUI to be "close to nature" and to enjoy its benefits are consciously pursuing a suite of ecosystem services that are readily accessible at that interface, and even those who move for economic reasons, such as more affordable housing in some areas, may appreciate their semi-natural surroundings. Specifically, homeowners at the WUI, whatever their initial motivation for moving there, often value aesthetics and recreational opportunities (cultural services), a cleaner environment (provisioning services), and the opportunity to observe and interact with charismatic and desirable species such as birds and wildflowers (cultural services flowing from supporting services).

Not all aspects of ecosystem function are equally desirable, and settlers at the WUI often become upset when the less desirable aspects of ecosystem function invade their lives. While enjoying the ecosystem services they wanted, people living in the WUI simultaneously encounter a different suite of ecosystem functions and products that they didn't want, but which nevertheless still result from a healthy ecosystem. These less desirable aspects of the WUI experience include exposure to insects such as mosquitoes, ticks, and fire ants; diseases spread by wild animals, such as Lyme Disease and hanta virus; and new allergies from new pollens. In addition, healthy ecosystems on the wildland side of the WUI have predators that can range from poisonous snakes to owls large enough to carry off small pets to, potentially, physically dangerous mammals like cougars/mountain lions, coyotes, wolves, and bears, none of which are generally welcome in residential neighborhoods.

As such, development at the WUI can create a multifaceted desire on the part of new residents to control several "undesirable" products of ecosystem function while simultaneously promoting the ecosystem services that they desire. The residents' "ideal" suite of ecosystem services, however, may not be compatible with the continuing existence of the ecosystem to which they moved. At the extreme, as the Introduction noted, these WUI settlers suffer from the wildfires that their own activities often cause or promote (Radeloff et al. 2018). More subtly, however, resident pressure to reduce or eliminate certain species or habitat can progressively undermine the overall health of the ecosystem they hoped to enjoy, simultaneously both frustrating wildland managers' management 
goals and impairing the desirable ecosystem services that residents seek to maintain. In other words, residents' understandable desires to pick and choose among the ecosystem services and functions they encounter pervasively complicates land use management on both sides of a line that is itself often either moving as a result of increasing development, changing into a transition or buffer zone as a result of development pressures, or fundamentally transforming as a result of climate change (Pierre-Louis and White 2018). This emergent behavior can build systemic risk, exposing local communities and the wildland ecosystem to cascade failures, including not only wildfire but also invasive species, pest outbreaks, and severely degraded habitat.

Adaptive management for ecosystem services, done correctly (Craig and Ruhl 2014), could help to effectively address these evolving issues at the WUI. In particular, it could simultaneously help to make transparent the potential and actual conflicts regarding how different suits of ecosystem services are valued and the trade-off and consequences likely to result from trying to pick and choose among them.

First, proper adaptive management brings all relevant stakeholders to the table (Craig and Ruhl 2014). At the WUI, therefore, adaptive management can provide a procedural forum through which all of the relevant landowners, land managers, government representatives, and non-governmental interest groups can be identified and brought together to formulate an adaptive management plan (or plans) to cover the appropriate geographic scale, despite fragmentation of ownership and political/governmental authority. The formulation of an adaptive management plan, moreover, can become the process through which all relevant stakeholders can negotiate toward, if not a common set of management goals, at least phased and mutually compatible sets of management actions that span the WUI's developed, transitional, and wildland components and that respect the management goals of each. The adaptive management planning forum thus can provide the actual negotiation context in which Miller et al.'s (2019) community-based informal governance plans, or Bradshaw and Lueck's (2015) multi-landowner contracts, or both, can actually emerge.

Second, adaptive management is a learning process (Craig and Ruhl 2014). It thus can become a procedural forum in which various stakeholders can learn that different ecosystem services are valued differently by different interests. For instance, both residents and wildland managers can identify which aspects (ecosystem services) of their shared environment they value and wish to retain as well as those aspects (services and functions) that they hope to change, allowing for discussions of potential conflicts and tradeoffs. Wildland managers, ideally, could also explain to residents why their wildfire risk might decrease if certain aspects of the ecosystem could be maintained at high functional valuefor example, natural processes and predators that keep at bay the diseases and pests that render plants and trees more flammable, or native trees and other kinds of plants that retain soil moisture and helps to maintain surface water and groundwater levels even in dry seasons.

Third, adaptive management gives all stakeholders the opportunity to experiment with new techniques to test both their efficacy and their compatibility with differentlyvalued ecosystem services (Craig and Ruhl 2014). Specifically, property owners and managers can mutually agree to test techniques such as forest or brush thinning or 
controlled burns to evaluate whether they reduce wildfire risk, improve ecosystem health, improve cultural services such as recreational access or aesthetic beauty, some combination, or are simply inappropriate to the location in question. They could similarly agree to test resident tolerance for undesirable native species and habitats - for example, poison oak (Bay Nature 2012; Team 2016) or poison ivy (Pike 2015) patches - through education about their important ecological roles and about more effective techniques for avoiding or co-existing with these species and habitats. Overall, the realization that the group can junk any failing experiment relatively quickly should increase the stakeholders' willingness to try new techniques that could potentially improve WUI management for all concerned, particularly if the risks are no greater than the existing threat of catastrophic wildfire.

Finally, proper adaptive management is in fact adaptive (Craig and Ruhl 2014). The recurring or continuing need for adaptation in a particular WUI could come from any combination of multiple sources, including increasing development, recolonization of abandoned settlement by the wildland (as is often the case in New England (Pierre-Louis and White 2018)), loss of native species, multi-year drought, flooding, wildfire, invasive species, new pests or diseases, change in legal status (endangered species listings, rezoning, wilderness designation or loss of designation nearby), or climate change. Through cycles of monitoring and re-evaluation, adaptive management can help to identify for all interested stakeholders the ecosystem functions and services in a WUI that are changing and whose continued preservation require management changes, whether through simple adjustments or through wholescale restructuring. As the particular WUI system gains or loses ecosystem services, all stakeholders are likely to be re-valuing the suite of ecosystem services and functions of particular interest to each, and the adaptive management process promotes both the identification of those changes and the re-negotiation of shared management plans and decisions in light of evolving desires and abilities to maintain particular ecosystem services.

Of course, not every group of WUI stakeholders currently possesses sufficient legal authority to pursue adaptive management, either individually or through partnerships with other stakeholders. Moreover, even if all relevant stakeholders have such authority, initial coordination to pursue adaptive management for ecosystem services is likely to require several new initial agreements and memoranda of understanding between multiple managers of mixed land use regimes laid out in a blotchy mosaic. Nevertheless, the combination of housing pressures and wildfire threats in many jurisdictions should often be sufficient to generate the political will to pursue such authorities and agreementsparticularly if the first few WUI communities to try adaptive management for ecosystem services experience success, and particularly if wildfire avoidance turns out, in fact, to be one of the benefits of pursuing adaptive management for ecosystem services.

\section{CONCLUSION}

Adaptive management for ecosystem services is a new management tool. There are many ways to do "adaptive management" wrong, and we have already argued elsewhere that new law is necessary to ensure that any adaptive management process is 
simultaneously scientifically valid, participatory and transparent, and publicly accountable (Craig and Ruhl 2014).

While we have argued that catastrophic wildfire at the WUI is the sign of more complex management problems across this varied interface, we also acknowledge the political salience of WUI wildfire problems. Indeed, increased interest in better managing the WUI to avoid wildfire disaster could provide governments with both the impetus and the political will to authorize true adaptive management for ecosystem services.

Adaptive management for ecosystem services at the WUI is not a panacea, nor will it be easy. Done correctly, however, it offers WUI stakeholders a productive forum in which to acknowledge that they value different suites of ecosystem services and functions differently, that there are short-term and long-term tradeoffs in privileging the ecosystem services desired by residents at the expense of other functions necessary for ecosystem health, and that improving certain ecosystem functions can provide the desirable service of reducing the risk of catastrophic wildfire. It also requires experimentation and learning, allowing the stakeholder communities in different WUIs to develop adaptive management plans that suit their particular social-ecological circumstances and goals and that can adapt to the specific changes that they experience over time at the particular landscape scale most appropriate to their WUI communities. 


\section{Literature Cited}

Alcasena, FJ, Evers, CR, and Vega-Garcia, C (2018). The wildland-urban interface raster dataset of Catalonia, Data In Brief 17: 124-128.

Allen, CR, and Gunderson, LH (2011). Pathology and failure in the design and implementation of adaptive management. Journal of Environmental Management 92: 1379-1380.

Bay Nature (2012). Poison oak has a good side, too, Retrieved from https://baynature.org/article/poison-oak-has-a-good-side-too/.

Baylis, P, and Boomhower, J (2019). Moral hazard, wildfires, and the economic incidence of natural disasters. Unpublished.

Biber, E (2013). Adaptive Management and the Future of Environmental Law. Akron Law Review 46: 934-962.

Bradshaw, K, and Leonard, B (20__ ). Virtual parceling. (this volume)

Bradshaw Schultz, K, and Lueck, D (2015). Contracting for Control of Landscape-Level Resources. Iowa Law Review 100: 2507-2549.

Burton, L (2018). In Dubious Battle: The Human Cost of Wildland Firefighting. Journal of Environmental Law \& Litigation 33: 87-128.

Costanza, R, de Groot, R, Braat, L, Kubiszewski, I, Fioramonti, L, Sutton, P, Farber, S, and Grasso., M (2017). Twenty years of ecosystem services: How far have we come and how far do we still need to go. Ecosystem Services 28: 1-16.

Council on Environmental Quality, Office of Management and Budget, and Office of Science and Technology (2015). Incorporating Ecosystem Services into Federal Decision Making (memorandum), Retrieved from https://obamawhitehouse.archives.gov/sites/default/files/omb/memoranda/2016/m-1601.pdf.

Craig, R, and Ruhl, JB (2014). Designing Administrative Law for Adaptive Management. Vanderbilt Law Review 67: 1-87.

Doremus, H (2011). Adaptive Management as an Information Problem. North Carolina Law Review 89: 1455-1495.

Doremus, H, Andreen, WL, Camacho, A, Farber, DA, Glicksman, RL, Goble, D, Karkkainen, BC, Rohlf, D, Tarlock, AD, Zellmer, SB, and Jones, S (2011). Making Good 
Use of Adaptive Management. Washington, DC: Center for Progressive Reform.

Elmqvist, Y, Setala, H, Handel, SN, Ploeg, S, Aronson, J, Blignaut, JN, GomezBaggethun, E, Nowak, DJ, Kronenberg, J, and de Groot, R (2015). Benefits of restoring ecosystem services in urban areas. Current Opinions in Environmental Sustainability 14: 101-108.

Epstein, RA (20_). Property rights: Long and skinny. (this volume).

Green, OO, Garmestani, AS, Albro, S, Ban, NC, Berland, A, Burkman, CE, Gardiner, MM, Gunderson, L, Hopton, ME, Schoon, ML, and Shuster, WD (2015). Adaptive governance to promote ecosystem services in urban green spaces. Urban Ecosystems 19: $77-93$.

Gruson, M (1987). The Global Securities Market: Introductory Remarks. Columbia Business Law Review 1987: 303-308.

Helbing, D (2013). Globally networked risks and how to respond. Nature 497: 51-59.

Iman Anabtawi, I, and Schwarz, SL (2011), Regulating Systemic Risk: Towards an Analytical Framework. Notre Dame Law Review 86: 1349-1412.

Kauffman, S (1995). At Home in the Universe: The Search for the Laws of SelfOrganization and Complexity. New York, NY and Oxford, UK: Oxford University Press.

Lant, CL, Ruhl, JB, and Kraft, SE (2008). The tragedy of ecosystem services. Bioscience 58: 969-974.

Luederitz, C, Brink, E, Gralla, F, Hermelingmeier, V, Meyer, M, Niven, L, Panzer, L, Partelow, S, Rau, A-L, Sasaki, R, Abson, D, Lang, D, Wamsler, C, and Wehrden. H (2015). A review of urban ecosystem services: Six key challenges for future research. Ecosystem Services 14: 98-112.

McFadden, J, Hiller, TL, and Tyre, AJ (2011). Evaluating the efficacy of adaptive management approaches: Is there a formula for success? Journal of Environmental Management 92: 1354-1359.

Millennium Ecosystem Assessment (2005). Ecosystems and Human Well-Being: Synthesis. Washington, DC: Island Press.

Miller, JH, and Page, SE (2007). Complex Adaptive Systems: An Introduction to Computational Models of Social Life. Princeton, NJ: Princeton University Press. 
Miller, SR (2017). Planning for Wildfire in the Wildland-Urban Interface: A Guide for Western Communities. Urban Lawyer 49: 207-266.

Miller, SR, Lindquist, E. Vos, j, Wuerzer, T, Mowery, M, Stephens, B, and Grand, A (2016). Planning for Wildfire in the Wildland-Urban Interface. Advocate 59: 42-45.

Miller, SR, Vos, J, and Lindquist, E (2019). "Informal Governance Structures and Disaster Planning: The Case of Wildfire." University of Arkansas at Little Rock Law Review XX: XXX-XXX (forthcoming).

Mitchell, M (2009). Complexity: A Guided Tour. New York, NY and Oxford, UK: Oxford University Press.

Naeem, S, Ingram, JC, Varga, A, Agardy, T, Barten, P, Bennett, G, Bloomgarden, E, Bremer, LL, Burkill, P, Cattau, M, Ching, C, Colby, M, Cook, DC, Costanza, R, DeClerck, F, Freund, C, Gartner, T, Goldman-Benner, R, Gunderson, J, Jarrett, D, Kinzig, AP, Kiss, A, Koontz, A, Kumar, P, Lasky, JR, Masozera, M, Meyers, D, Milano, F, Naughton-Treves, L, Nichols, E, Olander, L, Olmsted, P, Perge, E, Perrings, C, Polasky, S, Potent, J, Prager, C, Quétier, F, Redford, K, Saterson, K, Thoumi, G, Vargas, MT, Vickerman, S, Weisser, W, Wilkie, D, and Wunder S (2015). Get the science right when paying for nature's services. Science 347: 1206-1207.

National Research Council (2004). Valuing Ecosystem Services: Toward Better Environmental Decision-Making. Committee on Assessing and Valuing the Services of Aquatic and Related Terrestrial Ecosystems (NRC C-AVSARTE). Washington, DC: National Academies Press.

Ostrom, E (2009). A general framework for analyzing sustainability of social-ecological systems. Science 325: 419-422.

Palmer, M, and Ruhl, JB (2015). Aligning restoration science and the law to sustain ecological infrastructure for the future. Frontiers in Ecology and Environment 13: 512519.

Paveglio, TB, Jakes, PJ, Carroll, MS, and Williams, DR (2009). Understanding social complexity wthin the wildland-urban interface: A new species of human habitation. Environmental Management 43: 1085-1095.

Paveglio, TB, Moseley, C, Carroll, MS, Williams, DR, Davis, EJ, and Fischer, AP (2015). Categorizing the social context of the wildland urban interface: Adaptive capacity for wildfire and community "archetypes." Forest Science 61: 298-310.

Pierre-Louis, K., and White, J (2018). Americans Are Moving Closer to Nature, and to Fire Danger. The New York Times, Retrieved from 
https://www.nytimes.com/2018/11/15/climate/california-fires-wildland-urbaninterface.html.

Pike, S (2015). Nature News: Poison ivy has a role in our ecosystem despite being a nuisance. Fosters.com, Retrieved from https://www.fosters.com/article/20150905/ENTERTAINMENTLIFE/150909767.

Radeloff, VC, Helmers, DP, Kramer, HA, Mockrin, MH, Alexandre, PM, Bar-Massada, A, Butsic, V, Hawbaker, TJ, Martinuzzi, S, Syphard, AD, and Stewart, SI (2018). Rapid growth at the US wildland-urban interface raises wildfire risk. Proceedings of the National Academy of Sciences (PNAS) 115: 3314-3319.

Reilly, B (2015). Free Riders on the Firestorm: How Shifting the Costs of Wildfire Management to Residents of the Wildland-Urban Interface Will Benefit Our Public Forests. Boston College Environmental Affairs Law Review 42: 541-576.

Ruhl, JB (2008). Agriculture and Ecosystem Services-Strategies for State and Local Government. NYU Environmental Law Journal 17: 424-459.

Ruhl, JB (2010). Ecosystem Services and Federal Public Lands. Duke Environmental Law and Policy Forum 20: 275-290.

Ruhl, JB (2015). In Defense of Ecosystem Services. Pace Environmental Law Review 32: 306-335.

Ruhl, JB (2016). Adaptive Management of Ecosystem Services Across Different Land Use Regimes. Journal of Environmental Management 183: 418-423.

Ruhl, JB, and Katz, DM (2014). Measuring, Monitoring, and Managing Legal Complexity. Idaho Law Review 101: 191-244.

Ruhl, JB, Lant, C, and Kraft, SE (2007). The Law and Policy of Ecosystem Services. Washington, DC: Island Press.

Ruhl, JB, and Salzman, J (2007). The Law and Policy Beginnings of Ecosystem Services. Journal of Land Use \& Environmental Law 22: 157-172.

Salzman, J (2006). A Field of Green? The Past and Future of Ecosystem Services. Journal of Land Use \& Environmental Law 21: 133-151.

Samet, RH (2013). Complexity, the science of cities and long-range futures. Futures 47: 49-58. 
Scarlett, L, and Boyd, J (2011). Ecosystem Services: Quantification, Policy Applications, and Current Federal Capabilities. Washington, DC: Resources for the Future.

Scarlett, L, and Collins, S (2014). Introduction to agency use. In Federal Resource Management and Ecosystem Services Guidebook. Raleigh, NC: National Ecosystem Services Partnership, Duke University.

Susskind, L, Camacho, AE, and Schenk, T (2012). A critical assessment of collaborative adaptive management in practice. Journal of Applied Ecology. 49: 47-51.

Team, B (2016). The Surprising Importance of Poison Oak. Saano Adventures, Retrieved from https:/www.saanoadventures.com/saanoadventures-blog/2016/3/24/the-surprisingimportance-of-poison-oak.

Temmerman, S, and Kirwan, ML (2015). Building land with a rising sea. Science 349: 588-589.

The Economics of Ecosystems and Biodiversity (TEEB) (n.d.). Glossary of terms, Retrieved from http://www.teebweb.org/resources/glossary-of-terms/.

Trego, GD (2012). We Didn't Start the Fire . . . and We Won't Pay to Stop It: Financing Wildlife Management in America's Wildland-Urban Interface. William \& Mary Environmental Law \& Policy Review 36: 595-634.

United States Forest Service (USFS) et al. (2001). Urban Wildland Interface Communities Within the Vicinity of Federal Lands That Are at High Risk From Wildfire. Federal Register 66: 751-777.

United States Forest Service (USFS) (2012). National Forest System Land Management Planning. Federal Register 77: 21162-21276.

Williams, BK (2011). Adaptive management of natural resources-Framework and issues. Journal of Environmental Management 92: 1346-1353.

Williams, BK, and Brown, ED (2012). Adaptive Management: The U.S. Department of the Interior Applications Guide. Washington, DC: U.S. Dep't of the Interior. 